\title{
What it Require to Become an Accounting Partner? Insights from Lived Experiences of Accounting Partners in the Kingdom of Saudi Arabia
}

\author{
Sami Sobhi Waked* \\ sami.waked@nbu.edu.sa \\ College of Business Administration \\ Northern Borders University Arar- Suadi Arabia Kingdom \\ Mohd. Atef bin Md Yusof \\ atef@uum.edu.my \\ Tunku Puteri Intan Safinaz School of Accountancy \\ University Utara Malaysia
}

\begin{abstract}
This qualitative study aims at identifying the essence of personal experiences of accounting partners in Saudi Arabia. For this phenomenology approach employs to understand the lived experience of accounting partners and how would such experience affect their career. It mainly aims to explore the different experiences of fifteen (15) Saudi partners working in various accounting companies in Saudi Arabia. The interviews conducted to explore the most important challenges and difficulties for accountants to become a partner, and the most important job skills that the partners must have. This study found that there is urgent need for a number of things, including the required number of years of experience to become a partner, and to make sure that the partners are having the right education and professionally qualified. In addition, other different skills that the partner must have include responsible leadership, professional communication, good marketing skills and excellent command of English. Moreover, this research is vital for the concerned parties to identify the current challenges in the accounting profession in Kingdom of Saudi Arabia.
\end{abstract}

Keywords: Accounting, Saudi Arabia, Partners.

\section{Introduction:}

The nature of career paths in the professional accounting firms has drawn the attention of both professional and academic accounting researchers since long (Almer, Lightbody, Single, \& Vigilante, 2011). The term partner is still considered as a symbol of prestige, expertise and leadership in the world of job titles, but becoming partner is widely regarded as a badge of achievement, the route to partner can seem impenetrable to new entrants into the accounting profession (Young, 2014). The role of the partners is continuously changing, and future partners will need to be adaptable, ambitious and resourceful if they want to make it to the top (Young, 2014).

But many potential accountants are unclear about their career path (White, 2014). As the accounting firms primarily hire from top ten percent of the graduating class, but this does not guarantee success. Recruiters know that the vast majority will leave and only one in a thousand 
will actually progress to become a partner (Satatva, 1999). In the Kingdom of Saudi Arabia (KSA) the President of the Saudi Organization for Certified Public Accountants (SOCPA) has pointed out that in the accounting profession it is noted that the percentage of Saudis working in this important area does not exceed 24\%, the biggest challenges that have risen in the profession in the Kingdom of Saudi Arabia is the rapid developments that are wildly circulating in the world, especially in the areas of economic and accounting, making the development of the accountancy profession a fundamental requirement (Al-Angari, 2007). The "Big Four" is a term coined in 2002 which refers to the four remaining large companies in the international accounting firms after the collapse of Arthur Andersen, "Price Waterhouse Coopers, Deloitte, Ernst \& Young and KPMG" (Francis and $\mathrm{Yu}, 2009)$.

These Big Four firms are also present in the Kingdom of Saudi Arabia with some affiliations with local firms. The study noted a decrease in the percentage of new partners who are under the age of 36 years, from $73 \%$ to $49 \%$ because the job of an accountant is full of risks such fears of making errors and low salaries particularly in the early years of job and it is one of the major reasons of not adopting the accountancy as a profession (Satatva, 1999). The graduates working in accounting firms tend not to stay longer in their work and to be tired of the job because accounting in big firms tends to require a lot more duties and carry heavier responsibilities (Satatva, 1999).

This study attempts to describe the reasons why there are not many Saudis staying in this profession despite the urgent call for the Saudi Arabian citizens to occupy this profession and to stop the perception that this career is not important. The Kingdom of Saudi Arabia has a serious shortage of skilled Saudi workers, especially in the services sector (Baqadir, Patrick, \& Burns, 2011).

The accounting profession and the Big 4 firms have long been faced with staff shortages and concerned about the short supply of bright accounting graduates willing to choose a career in public accounting. Whilst much has been written in recent years about the Big Four, it has been remarked that "relatively little is known about the identity of partners" (Kornberger, Justesen, \& Mouritsen, 2011, p. 515).

Educational researchers have highlighted, and employers have complained about the mismatch between employees skills and the expectations of employers in Saudi Arabia (Ramady, 2010). It is expected that this study will help in establishing better new working conditions for those who work in the accounting profession. Moreover, it is expected that the study will help Saudi accountants who aim to work in major accounting firms, and have the ambition to become partners in the accounting firms.

The present study focuses on the partners in the accounting firms in Saudi Arabia and the problems and difficulties that face Saudi accountants in becoming partners in the local and international accounting firms.

\section{Literature Review:}

This research study focuses on the lived experience of becoming accounting partners in the Kingdom of Saudi Arabia, this chapter discusses the required job skills and challenges faced by 
the accounting partners of the accounting and auditing firms. (L. D. Parker, Guthrie, \& Linacre, 2011) argue that accounting research has travelled far from the profession, resulting in the lack of useful knowledge of the professional practices at the present time. It is found that the accounting job is regarded as one of the most important professions (Ding, Hope, Jeanjean, \& Stolowy, 2007; Wyatt, 2004; Zeff, 2003). As practitioners think that there is a gap in the accounting field, they have regarded the importance of goals in the accounting research as to improve the environment of the accounting practices, rather than providing a description or criticism that calls for building links between research results and the accounting community (L. D. Parker et al., 2011).

Al-Shammari et al. (2007) has shown that the governments of the GCC countries are involved in the regulation of the financial standards and they control the accounting and auditing professions. The percentage of the Saudis working in accounting profession is quite low as compared to other countries. The number of Saudis working in accounting does not even exceed $28 \%$ (El-Firjani \& Faraj, 2016).

Historically, public accounting career paths have been "up or out," with the standard career progression being from staff to senior to manager to senior manager to partner (Almer et al., 2011). According to the system of accountants in the Kingdom of Saudi Arabia, partners are entitled to sign the audit report, and due to the small number of Saudis partners, this is not something common in the country.

Brierley (2000), examined the relationship between the professional performance examination and the accountants' perceptions of the level of their workload, attitudes of job satisfaction, organizational commitment and intention to leave the firm in England. He has theorized that accountants' workload, job satisfaction, organizational commitment and intention to leave their firm are not related to professional performance examination. The results reveal that there are no significant relationships between above stated variables. Any attempt by certified accountant firms to change the work environment is unlikely to affect the professional performance examination.

The broad career structure is much the same across the three contexts: following qualification, employees move into the manager position - during which time many tend to leave the firm before proceeding to senior manager, director and ultimately partners. Only two to three percent of members of the Big Four will ever make partner; ascension to this position is to enter the elite of the accounting profession. In provincial cities, Big Four partners are well known business celebrities, while in capital cities they are players within their service lines. Partners are the pinnacle of the accounting profession for those that remain in private practice (Carter, 2014; Irvine, 2014).

The accounting profession worldwide has come under close scrutiny in the last decade as a result of a series of continued failures, changing technology and globalization of the world economy (Albrecht \& Sack, 2000; Germanou, Hassall, \& Tournas, 2009). These factors have reduced the cost of information and increased the level of competition among organizations. This has resulted in a need for rapid and more decisive actions by the management, an emergence of new companies or industries and a necessity for new professional services and skills. 
Likewise, De Lange, Jackling, and Gut (2006) found that the accounting curriculum has failed to provide skilled and well-equipped professional accountants according to the needs of the market, despite strong demand for specialized manpower. While, the employers are seeking a diverse range of skills and attributes in new graduates in order to maintain a competitive advantage, despite the fact that many countries are facing skill shortage in the area (Birrell, 2006).

Recently, the training and development of accountants worldwide have been the subject of much debate and political struggle (Mohamed \& Lashine, 2003). Factors including independence, concern for the public interest and performance expectations, accountants committed to have many skills, and obliging them to keep continuing professional development during the years of work (Cooper, 2002; Howieson, 2003).

The professionals in Accounting profession suffer from many problems, especially in terms of job satisfaction and high job turnover rate (Ghani, Said, Nasir, \& Jusoff, 2009; McDowall \& Jackling, 2010). The researcher has used McClelland's theory, which has not been previously applied to examine job satisfaction, because it might provide a conceptual explanation as to why some individuals experience relatively high level of job satisfaction in the workplace, while those who have little or insufficient experiences have a relatively low level of job satisfaction (Harrell Michael \& Adrian, 1984).

Alsaad and Darweesh (2008) believed that the supervision of accounting professionals in the KSA must focus on the quality of performance in order to be in line with their interest to contribute to the development of the accounting profession. Despite this professional interest in the performance, there are remarks and signs that indicate the presence of irregularities affecting the performance of accounts professionals. Meanwhile, it is indicated that accounts professionals have to face a number of challenges since the beginning of their work and during their training.

Organizational justice in the accounting profession has become one of the main issues that have been addressed, especially when the employee wishes to leave his job at the accounting firm to work in another. Justice in the accounting profession is an important requirement in the eyes of some accountants and its absence means discrimination and racism. This, undoubtedly, leads to a decline in job satisfaction and to a high rate of job-quitting and looking for a better alternative (R. Parker \& Kohlmeyer, 2005).

However, it is essential to differentiate between job satisfaction and job performance because there is a conflict and ambiguity regarding the work. It is argued that an employee can perform his/her job, but at the same time may not satisfied with the nature of his/her job (Fisher, 2001).

The impact which occurs when the accountants leave the accounting organizations voluntarily or reluctantly is substantially important. Also, calculating the exact cost of this impact is difficult. Therefore, personnel turnover rate has an important effect on organizations' operating costs and is directly related with the recruitment of the employees and training costs, low level of employee's morale, job satisfaction and perception of customers about service quality (Hancock, Allen, Bosco, McDaniel, \& Pierce, 2013). There are a number of basic capabilities of the people who work in the accounting profession. These include the awareness of using technological programs in accounting. It is important that any new accounts must be able to deal with the modern 
technologies. Now, according to some studies, it is found that it is important for the auditors to learn some relevant technology, especially Excel program, in the view that technology is an important tool for this profession (Harrast, Strong, \& Bromley, 2010). The accounting jobs were rated among the five most skills required jobs in the world (Davis, Farrell, \& Ogilby, 2010).

According to the International Federation of Accountants (IFAC) and American Institute of Certified Public Accountants' (AICPA), the accounting profession has become a claim development, so that work must involve many public accountants' skills, such as financial analysis, communication, leadership and interpersonal skills. Meanwhile, many of the studies have reported the lack of general skills of the individuals involved in the accounting profession at the beginning of the work (Ballantine \& McCourt Larres, 2009; Manna, Bryan, \& Pastoria, 2009; Sugahara, Suzuki, \& Boland, 2010).

The accounting profession is a profession that requires efficient computer-based accounting skills. This creates competition among accounting companies to have the most recent programs to fit and live up to their reputation. As a result, this requires software companies to design new programs that can meet the expectations of employers. These qualities have been mentioned in the American Institute of Certified Public Accountants (Ballantine \& McCourt Larres, 2009).

Female employees are important to any organization. The undeniable importance of human capital for the accounting profession, and because of the low numbers of female auditors following some social reasons believe that it is necessary to study the causes of this decline, and it must continue to share the goal of the gender to work, especially in the accounting profession (Law, 2010).

In Saudi Arabia, there are more than 23,000 businesswomen and SR 62 billion in untapped bank accounts, as well as the fact that there are 10 Muslim women in 100 executives in the world, which means that women are considered the challenge as their number is rising in the labor market compared to men and more and more women are becoming certified accountants (Sadi \& AlGhazali, 2010).

\section{Research Methodology}

In this chapter, the underlying research philosophy is discussed along with phenomenology as a qualitative research methodology. After that, choice of respondents and the research participants are given followed by the semi-structured interviews method of data collection. These are followed by the method of qualitative data analysis proposed by Moustakas (1994). The utilization of qualitative research methods enables the researchers to understand the societal or cultural context on which the research is based on. For instance, data quantification may not facilitate the social and institutional background of the research unlike qualitative method (Kaplan \& Maxwell, 2005). Furthermore, a qualitative method of study is suitable for the present study as it attempts to examine the meaning behind being a partner in the accounting firm. The definition of the qualitative approach may also encapsulate the concept whereby the research make use of it to develop complex, holistic picture of the research topic in an actual environment (Creswell, 1998), which serves the purpose of the present study's objectives. In present research study, interviews 
are used as the primary tool for data collection. In particular, interviews are conducted with the partners working in the local and international accounting and auditing firms in Saudi Arabia.

As previously mentioned, the present study employs the qualitative research format to examine accounting firms in an attempt to understand each firm's nature with regards to the number of partners, their gender, and the firm branches and type (either local or global). The same type of research method was employed by (Halabi, Barrett, \& Dyt, 2010) to shed a light on the financial information employed for the assessment of small companies performance, where they interviewed small groups of firms. Similarly, Law (2010) used the qualitative method to investigate the reasons behind the lack of female checkers in Hong Kong's accounting sector. Therefore, present research seeks answers to the questions of 'What are the professional and nonprofessional skills required by the accountants to become partners in accounting firms in Saudi Arabia?', 'What are the obstacles / challenges faced by auditors or accountants to become partners in accounting firms?' and 'How did the partners meet the challenges until they reach partner's level?'. While other open-ended questions may be added to the above three questions, they especially aim at gathering data that will result in textural description and structural description of the experiences and eventually facilitate an understanding of the participants' common experiences.

The interviews took place in two Saudi major cities namely Jeddah and Riyadh because these two cities are the main locations of audit firms. The researcher used purposeful sampling for selecting research participants. The purposive sampling is used for the selection of sample units because this sampling technique allows to select a sample keeping in my a particular purpose and because their ascendency captured the lived experiences associated with the topic under investigation (Babbie, 2015). Moreover, as argued by (Bryman, 2015) and (Babbie, 2015), purposive sampling is a type of non-probability sampling and it is popular in qualitative research. In addition they defined purposive sampling as to select a sample on the personal judgment of the researcher.

\subsection{The Research Participants}

The categories of the participants in present research and the cities their accounting firms are located in are presented in Table 3.1. It is evident from the table that in the months from August 2013 to May 2014, the researcher managed to interview 15 partners. The table displays the user group, where the interviewed individuals are categorized under ' $\mathrm{P}$ '. The respondents chosen by the researcher are comprised of partners in accounting firms in Saudi Arabia located in two big cities, who possess high level of expertise in their fields.

All the respondents hold a professional fellowship from the Saudi Organization for Certified Public Accountants (SOCPA), while some of them have additional professional certificates.

Table 3.1

Partners Group

\begin{tabular}{lll}
\hline Interviewee's Code & Position & City \\
\hline P1 & Audit Partner in Big Four & Jeddah \\
P2 & Audit Partner in Big Four & Jeddah \\
P3 & Audit Partner & Jeddah \\
\hline
\end{tabular}




\begin{tabular}{lll}
\hline P4 & Audit Partner & Jeddah \\
P5 & Audit Partner in Big Four & Riyadh \\
P6 & Audit Partner & Jeddah \\
P7 & Audit Partner in Big Four & Jeddah \\
P8 & Audit Partner & Riyadh \\
P9 & Audit Partner in Big Four & Jeddah \\
P10 & Audit Partner in Big Four & Riyadh \\
P11 & Audit Partner & Jeddah \\
P12 & Audit Partner in Big Four & Jeddah \\
P13 & Audit Partner & Riyadh \\
P14 & Audit Partner in Big Four & Riyadh \\
P15 & Audit Partner in Big Four & Riyadh \\
\hline
\end{tabular}

Semi-structured interviews were employed in present research. The research employed semistructured interviews as the primary tool for data collection. The interview process comprised of two individuals or groups; the interviewer and the interviewee or the respondent. The interviewer asks the respondent to respond to questions in order to obtain the required information (Bryman \& Bell, 2015). To gather the kind of verbal data noted by Giorgi (1997), open-ended and informal questions are used during the in-depth face-to-face interviews.

The procedures followed in employing the semi-structured interviews are discussed in this section. The interview process took nine months from August 2013 to May 2014. From a total of 25 individuals who were listed as respondents, ten backed out and hence, only the remaining 15 were interviewed through face-to-face semi-structured interviews. The interviewer ensured that the interview venue had a good atmosphere, devoid of noise and obstructions for effective recording. Interviews are conducted with 15 partners included in the Saudi Organization for Certified Public Accountants (SOCPA), and each interview lasted from 23 minutes to 90 minutes.

The interview questions concluded with personal perceptions about their experience as partners in accounting firms with identifying the challenges and difficulties they faced and how they overcame those difficulties. The respondents provided insightful responses and valuable narrative descriptions to each question. The study participants spoke candidly, relying on their experiences. The total number of words, total transcription pages and interview durations are outlined in Table 3.2 below.

Table 3.2

Manifest Content Analysis

\begin{tabular}{llll} 
Participant & Interview Duration & Word Count & Total Transcription Pages \\
\hline P1 & 40 minutes & 2374 & 8 \\
P2 & 50 minutes & 1288 & 6 \\
P3 & 23 minutes & 1627 & 7 \\
P4 & 39 minutes & 2886 & 11 \\
P5 & 37 minutes & 2212 & 11 \\
P6 & 50 minutes & 2402 & 11 \\
P7 & 29 minutes & 1540 & 8 \\
P8 & 89 minutes & 3760 & 16 \\
\hline
\end{tabular}




\begin{tabular}{llll}
\hline P9 & 32 minutes & 2029 & 9 \\
P10 & 68 minutes & 2574 & 11 \\
P11 & 37 minutes & 1986 & 10 \\
P12 & 46 minutes & 1722 & 7 \\
P13 & 45 minutes & 2016 & 9 \\
P14 & 90 minutes & 3001 & 13 \\
P15 & 70 minutes & 1389 & 7 \\
\hline
\end{tabular}

\subsection{The Method of Data Analysis}

A qualitative analysis involves working with research evidence, organizing it, categorizing it into units synthesizing, pattern searching, outlining the important parts to be learned and determining what to relay to others (Bogdan \& Biklen, 1998). The first phase of data analysis is to create a textural description of each participant's lived experience. The second phase is called the structural description of the phenomenon, which is a reflective or interpretive phase. In order to carry out the textural analysis in present study, first a summary is created of the descriptive context of each participant. In addition, an organized and prioritized version of each person's experience is created. For this purpose, the transcriptions of the interviews for each participant were read multiple times by the researcher. The next step is to create an outline of the experience. This outline allowed the essence of the experience to unfold. Seeing the details written out on paper allowed for connections to be made between ideas and overlapping ideas to be consolidated. It also allowed for the best examples of overlapping ideas to be selected. Finally, the outline allowed for the prioritizing of themes that were essential from those that were incidental. In addition, during data collection and analysis, the constant comparative method is relied upon to help in developing themes and creating the interpretation. In conjunction with the hermeneutic circle, the themes are developed through the process of horizonalization. This process included forming an initial interpretation and supporting it with structural descriptions. These statements included cognitive, emotional, and religious acts (Anderson et al., 2001; Lickona, 1999; Russell, 2007), as well as words, phrases, etymologies, metaphors, and analogies (van Manen, 1990).

\section{Data Analysis}

The analysis is broadly categorized into two main sections. First section offers the textural description of the collected data through interviews regarding lived experiences of the participants. Second part of the analysis discusses more about the themes developed from the hermeneutic circle and principles of horzonalization. The information presented was obtained from the responses shared by each participant during the interviews. An amalgamation of the participants' stories is provided to describe the essence of the lived experience in the accounting profession until they became partners. They have all been assigned a pseudonym to maintain confidentiality.

\subsection{Textural Description}


This section presents the textural analysis for the collected data through interviews. The summary of participants' narratives is given in the descriptive context.

Based on the interview of one of respondent named Yaser, researcher found that computer/IT skills, English language skills, self supervision, moral \& occupational commitments are key job skills required to become partner in accounting firms of KSA. On the other hand, professional errors, professional clashes, racial discrimination and non-favorable social circumstances for women are the responsibility of Saudi partners.

Another respondent elaborated some of the key job skills required to become a partner in accounting firms in Kingdom of Saudi Arabia are strong and effective personality, professional accounting fellowships, relevant job experience, public relations and analysis and moral commitment and adherence. Whereas; the challenges are computer literacy, professional clashes and English language. Respondent named Abd Al-Kader's lived experience in becoming a partner in accounting firm in Kingdom of Saudi Arabia, some of the key job skills required to become a partner in accounting firms in Kingdom of Saudi Arabia are good English language, electronic auditing, Saudi fellowship and patience for promotion despite low wages. While, racism and transportation issue for women are obstacles as female gender is not allowed to drive car in Saudi Arabia.

Another respondent identified professional experience, English language, marketing skills, \& leadership skills are key job skills which are required to become partner in Saudi accounting firms. On the other hand, the challenges to become partners in accounting firms in KSA as found by researcher by these interviews are long working hours, racism and inappropriate environment for women. Respondent Waleed's lived experience in becoming a partner in accounting firm in Kingdom of Saudi Arabia, he identified Saudi fellowships patience and commitment and respect for work schedule. On the other hand, challenges are to have work life balance, gender discrimination against women and transportation for female.

Respondent Mohammad identified additional key job skills for the under discussed purpose includes self-development, administrative performance, spirit of initiative, self-judgement and analytical ability. He also embarked about the challenges are unclear protection rules and strict punishment in case of errors. Another respondent identified that interpersonal skills, knowledge, work life balance, and professional standards along with ambitions are key skills required for the said purpose of becoming partner in accounting firm in KSA. The challenges include women's limitation and family responsibilities.

Hardworking, ambitions, communication skills, English language skills, professional experience, leadership skills, and computer literacy are the key job skills required for the said purpose of this researcher paper addressed by another respondent named as Khalid. Racism and gender discrimination are the challenges faced by the partners in Saudi accounting firms identified by Khalid as respondent. Another respondent named Yaseen added other factors like professional certifications and commitment to work schedules for the purpose of becoming partner in Saudi accounting firms. Gender discrimination is the major challenge for KSA for partners in accounting firms. Respondent named Khalil also identified same points as key job skills requirement in order to become the partner in Saudi firms. He also included that challenges are gender discrimination 
and work life balance. Respondent Huda had same points to be identified for the said purpose and challenges related to female workers include discrimination and work life balance. Moreover, women are also facing additional challenges of family and social obligations. Transport is also a major problem for women in KSA as driving is not allowed to women there. Covered attire also works as a challenge in the marketing aspect of the job of a partner.

Additional key job skills such as knowledge about change in accounting standards and business system of KSA, as well as discipline and consistency are important to be consider in order to achieve purpose of research paper. Challenges identified by Hussain include emotions and confidence on one's own country mates are needed to be considered. In addition, there is transportation problem for women in KSA as women are not allowed to drive there. Respondent named Al-Nader identified adequate professional training, strong personality and hardwork is required to become a partner in Saudi accounting firms. As far as the challenges in becoming partners in accounting firms in KSA are concerned, Al-Nader affirmed that stress, racism, the presence of non-saudi fixed term partner and illegal Saudi working as advisers and partners are the major challenges. Talking about women presence in the accounting profession, he asserted that it is hard for women to persist and compete in this profession as he has not seen women working in this profession and time is required to consolidate the place of women in accounting profession.

Another respondent named Sami identified the same key job skills as previous respondents with the addition of clear objectives and clear vision in order to become a partner in accounting firms in Kingdom of Saudi Arabia. Challenges are inexperience, lose control of SOCPA over companies, racism and carelessness by media and society are important hurdles. Talking about women presence in the accounting profession, he asserted that the presence of women in accounting profession is recent. At the end respondent Ihssan added new factor of contemporary knowledge of accounting and auditing standards, patience, interpersonal and communication skill and commitment to work schedules to the previous respondents in order to become Saudi partner in accounting firms. . Talking about the challenges in becoming partners in accounting firms in KSA are concerned, Ihssan asserted that long working hours in rush periods, racism and discrimination are the major challenges. Talking about women presence in the accounting profession, he asserted that the women face additional challenges and problems in KSA.

\subsection{Thematic Analysis of the Data}

Hemes are the horizons or views of the phenomenon held by the participants (Moutakas, 1994; Van Manen, 1990). A total of six major themes were derived from the data analysis. Following figure presents a graphic representation of the underlying themes based on the textural description of the collected information. All the participants shared about experience, gender, professional certification, work environment, interpersonal skills, English language skills and partnerships in KSA. Following thematic diagram is derived from the interviews from different participants.

Figure: 1

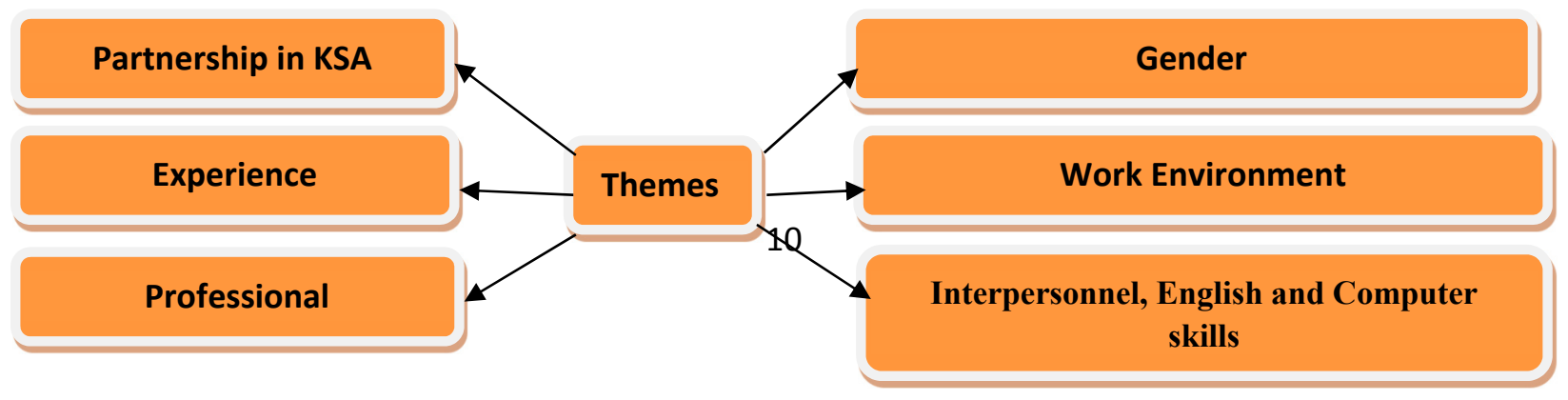




\section{Conclusion of the Study}

This research sheds a light on the description and understanding lived experiences of partners of accounting firms regarding the job skills required and the challenges in becoming a partner in accounting firms in the Kingdom of Saudi Arabia in order to seek the answers of the research questions. The objective was to conduct an analysis of the partners' viewpoint concerning their experience of becoming a partner in their firms.

The careful analysis of the collected data through interviews revealed that the required job skills required to become a partner in accounting firms in KSA are English language skill, computer skills including electronic auditing, marketing skills, interpersonal skills, leadership skills, self supervision, moral and occupational commitments, relevant job experience, Saudi fellowship along with other professional certifications, patience, prospective outlook, analysis, invention and innovation skills, ambition, hard work and consistency. On the other hand, the challenges faced by the partners to reach this position were primarily stress, racism, gender discrimination, work life balance and the presence of incompetent Saudi partners in the companies. These identified required job skills and challenges to become a partner in accounting firms in KSA are categorized into six distinct themes as; experience, partnerships in KSA, interpersonal and basic language and computer skills, professional certification, work environment and gender.

The contribution of present research is manifold. First, it contributes to the existing body of empirical literature pertaining required job skills and challenges faced by partners in accounting firms in general and in Kingdom of Saudi Arabia in particular as the research studies of this area are still lacking and what few there are, were culled through peer-reviewed publications.

\section{Limitations and Recommendations}

No study is without its limitations in terms of design, methodology, data accessibility and the study results interpretation. the participants are Saudis, limitation in the form of culture, regulations and the country's system also exist. Hence, the study findings may not be suitable to be extended to other countries. Furthermore, limitations can also be observed in terms of the level of experience of the partners, who possess varied knowledge and experience in auditing firms.

In addition, the present study recommends the following:

1. The need for giving attention to partnership in the accounting profession by issuing regulations and decrees in a clear and written form.

2. The need for combining the efforts of all the relevant stakeholders, from the accounting firms in all of their forms and sizes, to the Ministry of Trade represented by the Saudi Organization for Certified Public Accountants (SOCPA). 
3. The importance of following up on the situation of partnerships in the accounting profession, and resolving any matters that lead to deficiency in organizing the profession.

\section{References:}

Albrecht, W., \& Sack, R. (2000). Accounting Education: Charting the Course through a Perilous Future (Sarasota, FL: American Accounting Association).

Almer, E. D., Lightbody, M., Single, L. E., \& Vigilante, B. (2011). New leadership tracks in accounting firms: An alternative to the partnership. Current Issues in Auditing, 5(1), A39A53.

Babbie, E. (2015). The Practice of Social Research: Nelson Education.

Ballantine, J., \& McCourt Larres, P. (2009). Accounting Undergraduates' Perceptions of Cooperative Learning as a Model for Enhancing their Interpersonal and Communication Skills to Interface Successfully with Professional Accountancy Education and Training. Accounting Education, 18(4-5), 387-402.

Baqadir, A., Patrick, F., \& Burns, G. (2011). Addressing the skills gap in Saudi Arabia: does vocational education address the needs of private sector employers? Journal of Vocational Education \& Training, 63(4), 551-561.

Birrell, B. (2006). The changing face of the accounting profession in Australia. CPA Australia.

Bogdan, R. C., \& Biklen, S. K. (1998). Qualitative research in education. An introduction to theory and methods: ERIC.

Brierley, J. A. (2000). An analysis of the impact of the work environment on chartered accountants' professional examination performance. The Journal of social psychology, 140(3), 397-398.

Bryman, A. (2015). Social Research Methods: Oxford university press.

Bryman, A., \& Bell, E. (2015). Business Research Methods: Oxford University Press, USA.

Carter, C. (2014). The qualities of a Big Four partner Retrieved 16 July 2014, from http://economia.icaew.com/finance/july-2014/essay-the-qualities-of-a-big-four-partner

Cooper, B. (2002). The accountant of the future. Accounting \& Business, 35-37.

Creswell, J. (1998). Qualitative inquiry and research design: Choosing among five traditions: Sage Publications, Inc. 
Davis, C., Farrell, R., \& Ogilby, S. (2010). Characteristics and Skills of the Forensic Accountant: New York, NY: AICPA.

De Lange, P., Jackling, B., \& Gut, A. M. (2006). Accounting graduates' perceptions of skills emphasis in undergraduate courses: an investigation from two Victorian universities. Accounting \& Finance, 46(3), 365-386.

Ding, Y., Hope, O. K., Jeanjean, T., \& Stolowy, H. (2007). Differences between domestic accounting standards and IAS: Measurement, determinants and implications. Journal of Accounting and Public Policy, 26(1), 1-38.

El-Firjani, E. R., \& Faraj, S. M. (2016). International Accounting Standards: Adoption, Implementation and Challenges. Economics and Political Implications of International Financial Reporting Standards, 231.

Fisher, R. T. (2001). Role stress, the type A behavior pattern, and external auditor job satisfaction and performance. Behavioral Research in Accounting, 13, 143.

Germanou, E., Hassall, T., \& Tournas, Y. (2009). Students' perceptions of accounting profession: work value approach. Asian Review of Accounting, 17(2), 136-148.

Ghani, E. K., Said, J., Nasir, N. M., \& Jusoff, K. (2009). The 21ST Century Accounting Career from the Perspective of the Malaysian University Students. Asian Social Science, 4(8), P73.

Halabi, A. K., Barrett, R., \& Dyt, R. (2010). Understanding financial information used to assess small firm performance: An Australian qualitative study. Qualitative Research in Accounting \& Management, 7(2), 163-179.

Hancock, J. I., Allen, D. G., Bosco, F. A., McDaniel, K. R., \& Pierce, C. A. (2013). Meta-analytic review of employee turnover as a predictor of firm performance. Journal of Management, 39(3), 573-603.

Harrast, S., Strong, J., \& Bromley, R. (2010). More Accounting Theory or More Information Technology? The Accounting Educators' Journal, 20.

Harrell Michael, J., \& Adrian, M. (1984). McClelland's trichotomy of needs theory and the job satisfaction and work performance of CPA firm professionals. Accounting, Organizations and Society, 9(3-4), 241-252.

Howieson, B. (2003). Accounting practice in the new millennium: is accounting education ready to meet the challenge? The British Accounting Review, 35(2), 69-103.

Irvine, J. (2014). The DNA of a Big Four partner Retrieved 06 May 2014, from http://economia.icaew.com/news/may-2014/the-dna-of-a-big-four-partner 
Kaplan, B., \& Maxwell, J. (2005). Qualitative research methods for evaluating computer information systems. Evaluating the Organizational Impact of Healthcare Information Systems, 30-55.

Kornberger, M., Justesen, L., \& Mouritsen, J. (2011). "When you make manager, we put a big mountain in front of you": An ethnography of managers in a Big 4 accounting firm. Accounting, Organizations and Society, 36(8), 514-533.

Law, P. (2010). Examination of the actual turnover decisions of female auditors in public accounting: Evidence from Hong Kong. Managerial Auditing Journal, 25(5), 484-502.

Manna, D., Bryan, L., \& Pastoria, G. (2009). Professors and Practitioners' Perceptions of the Need for Accountants to Possess Emotional Intelligence. Economics and Organization of Enterprise, 3(1), 17-33.

McDowall, T., \& Jackling, B. (2010). Attitudes towards the accounting profession: an Australian perspective. Asian Review of Accounting, 18(1), 30-49.

Mohamed, E., \& Lashine, S. (2003). Accounting knowledge and skills and the challenges of a global business environment. Managerial Finance, 29(7), 3-16.

Parker, L. D., Guthrie, J., \& Linacre, S. (2011). The relationship between academic accounting research and professional practice. Accounting, Auditing \& Accountability Journal, 24(1), 5-14.

Parker, R., \& Kohlmeyer, J. (2005). Organizational justice and turnover in public accounting firms: A research note. Accounting, Organizations and Society, 30(4), 357-369.

Ramady, M. A. (2010). The Saudi Arabian economy: Policies, achievements, and challenges: Springer Science \& Business Media.

Sadi, M. A., \& Al-Ghazali, B. M. (2010). Doing business with impudence: A focus on women entrepreneurship in Saudi Arabia. African Journal of Business Management, 4(1), 1 - 11.

Satatva, D. (1999). 26 things you should know before working for a national accounting firm. New Accountant, 15, 18-22.

Sugahara, S., Suzuki, K., \& Boland, G. (2010). Students' major choice in accounting and its effect on their self-efficacy towards generic skills: An Australian study. Asian Review of Accounting, 18(2), 131-147.

White, S. (2014). Work experience trumps accounting qualifications for entry-level jobs, 2014, from https:/www.accountancylive.com/work-experience-trumps-accountingqualifications-entry-level-jobs 
Wyatt, A. R. (2004). Accounting Professionalism-They Just Don't Get It! Accounting Horizons, 18(1), 45 - 54.

Young, K. (2014). Deciphering the DNA of a partner. Accountancy Live, 2014, from https://www.accountancylive.com/deciphering-dna-partner

Zeff, S. A. (2003). How the US Accounting Profession Got Where It is Today: Part I,". Accounting Horizons, 17(3). 